\title{
Top Management Team Shared Leadership, Market-Oriented Culture, Innovation Capability, and Firm Performance
}

\author{
Sanjay Kumar Singh ${ }^{(}$, , Manlio Del Giudice, Shlomo Y. Tarba $\left.{ }^{(}\right)$, and Paola De Bernardi $\left.{ }^{(}\right)$
}

\begin{abstract}
What drives performance of small- and medium-sized enterprises remains largely unanswered and this article is an attempt in that direction to fill in the gap and help evolve the body of knowledge. The article is designed to produce theoretical insights on how top management team (TMT) sharing leadership, market culture, and firm innovation capability, relates to firm performance. Drawing on the resource-based and the dynamic capabilities-based view, we propose that firm innovation capability mediates between the linkages of shared leadership and marketoriented culture with firm performance. In this article, we performe structural equation modeling on survey data collected from 336 small- and medium-sized enterprises in the United Arab Emirates to examine the proposed hypothesized model of the study. The results reveal that both shared leadership and market-oriented culture have positive effects on firm innovation capability. This article suggests that market-oriented culture mediates the relationships of TMT-shared leadership and firm innovation capability. Similarly, firm innovation capability mediates the influence of market-oriented culture and firm performance, and the influence of TMT-shared leadership and firm performance. This article contributes to advance theory and practices. This article also makes sound theoretical and practical contributions to the usage of the resource-based and the dynamic capabilities view in the domain of the small- and medium-sized enterprises.
\end{abstract}

Index Terms-Firm innovation capability, firm performance, market-oriented culture, shared leadership, small- and mediumsized enterprises (SMEs).

\section{INTRODUCTION}

$\mathbf{S}$ MALL- and medium-sized enterprises (SMEs) play critical role in the growth of a country as they have flexible decision-making processes and motivated to respond to the markets quickly than large firms [87]. At the same time, SMEs operate with limited resources and capabilities that impede their ability to conduct in-house research and developmental activities [116] to beat competitions, especially in the context of fast

Manuscript received June 3, 2019; revised July 26, 2019 and September 12, 2019; accepted September 23, 2019. Review of this manuscript was arranged by Department Editor D. Meissner. (Corresponding author: Sanjay Kumar Singh.)

S. K. Singh is with the College of Business, Abu Dhabi University, Abu Dhabi 59911, United Arab Emirates (e-mail: sanjay.singh@adu.ac.ae).

M. Del Giudice is with the University of Rome "Link Campus", 00165 Roma, Italy, and also with the Paris School of Business, 75013 Paris, France (e-mail: manlio.delgiudice@oasipc.com).

S. Y. Tarba is with Birmingham Business School, University of Birmingham, B15 2TT Birmingham, U.K. (e-mail: s.tarba@bham.ac.uk).

P. De Bernardi is with the Department of Management, University of Turin, 10124 Turin, Italy (e-mail: paola.debernardi@unito.it).

Digital Object Identifier 10.1109/TEM.2019.2946608 changing technology and market environments [87]. Therefore, firms should possess innovation capability to stay competitive as it increases barriers against imitations by the rivals, reduces the cost of production and/or services, and retain old customers as well as attract new ones and to drive firm performance [23], [98], [99]. Firm innovation capability refers to the process of collecting relevant market information and knowledge that firms leverage to develop new processes, services, and products to satisfy customers' needs and stay relevant in the markets [116]. Innovation capabilities of firms depend upon how well it collects relevant information, data, and knowledge about their competitors and customers [23], [98], [99]. However, SMEs face difficulty to improve innovation capabilities [14] as they are new and small in the competitive markets that frequently impede their abilities to benefit from methodical idea generation [39] to satisfy needs of the customers.

The extant literature depicts the importance of innovation capabilities in enhancing firms' competitive advantage and helping them sustain superior performance [24], [26], [29]. Several researchers suggest that top management team's (TMT's) shared leadership style [82], [92] and market culture [85] drives innovation capability and performance in large firms. Moreover, TMTshared leadership favors collective decision making to generate strategic alternatives and work together to reconcile paradoxes, if any [73] for generation of new ideas and creativity [71], [83], [93] for enhanced firm performance. However, what drives performance of SMEs remains largely unanswered and this article is an attempt in that direction to fill in the gap and helps evolve the body of knowledge. Drawing upon both resource-based view (RBV) and the dynamic capabilities view (DCV) as theoretical lenses, this article explores how do SMEs leverage their strategic resources namely shared leadership and market-oriented culture to improve upon their innovation capabilities for enhanced firm performance. SMEs should possess resources that are valuable, rare, imperfectly imitable, and nonsubstitutable [4] and supports innovation capabilities necessary to assimilate, construct, and reconfigure their resources and competencies [31], [106], [113] in the dynamic markets.

We believe that entrepreneurship connects investments in knowledge creation and economic development together [3] and this article contributes to advance theory and practices and it primarily makes three key contributions. First, this article advances the RBV and the DCV as theoretical lenses to understand the interplay of TMT-shared leadership and market-oriented 
culture to influence SMEs' innovation capability and performance. Second, this research is situated in the UAE context wherein entrepreneurship as a profession and passion is highly valued socially and well supported by the governmental agencies [56], as the SMEs contribute approximately $30 \%$ to the gross domestic product (GDP) of the UAE [40]. This article offers relevant practical suggestions to the UAE government agencies on how to leverage key resources and capabilities to enable SMEs to grow in the dynamic business environment. Last, but not the least, this article advances the aim of IEEE TRANSACTIONS ON ENGINEERING MANAGEMENT with respect to decision making and policy formulation on how to develop and sustain firm innovation capabilities for the benefits of the SMEs, the society, and the country.

The rest of this article is arranged as follows. Section II presents theory and hypotheses followed by methods in the Section III. We present the findings of this article and theoretical and practical contributions of this article in Sections IV. Section V concludes this article.

\section{THEORY AND HYPOTHESES}

\section{A. $R B V$ and $D C V$}

The RBV conceptualizes firm to possess unique packet of tangible and intangible assets and capabilities that are valuable, rare, inimitable, and nonsubstitutable (i.e., VRIN) to attain competitive advantage and superior performance [4]. As such, the intangible resources and capabilities (i.e., VRIN) help firms to develop inimitable, organization-specific core competencies to allow them to beat competitors by doing things differently [21]. Therefore, we posit that if these strategic resources and capabilities of firms found to be valuable to customers, rare, and difficult to imitate, then these resources contribute to competitive advantage and increases firm performance [4]. Extant literature supports this conception, and continues to recognize and categorize such strategic resources that meet the criteria as suggested in the RBV [66].

RBV originated initially in the discipline of strategic management [55]; it continues to evolve within the field of SMEs which necessitates a need to investigate whether different strategic resources are required by SMEs [55] to succeed in the todays' fierce competitive and dynamic markets. The key argument of the RBV is that competitive advantages are increased to the level that a firm holds its strategic assets [4], and the assertion of RBV with some limitations finds supports until date [21], [66]. Therefore, drawing on the RBV, we posit that a higher level of firm innovation capability drives firm performance. As such, firms that are intelligent to use their strategic resources namely TMT-shared leadership, market-oriented culture, and innovation capability will eventually obtain the benefits of a higher firm performance.

However, the RBV perspective has not gone unchallenged as they failed to satisfactorily explain why and how specific enterprise to achieve competitive advantage in conditions of fast and volatile change [31], [47], [106]. As a result, RBV has been extended to dynamic markets where the competitive scene is shifting the dynamic capabilities (DC) wherein organization "integrate, build, and reconfigure internal and external competencies" to address fast shifting business landscape [107, p. 516]. RBV emphasizes sustainable competitive advantage, whereas the DC focus on competitive survival in reply to the rapidly changing industry environment. The DCV of the firms refers to the capability of organization to persistently build, extend, or amend its asset [47] for the express purpose of delivering competitive advantage necessary for producing and supporting superior firm performance in the dynamic market [106].

Extant literature suggest that firms learn continuously to deal with sustainability-related issues and that pushes firms to develop sustainable DC [70] and integrate them into their core business for a long-term strategy for explicit purposes namely, access to key resources, social and environmental responsibility, and legitimacy [17], [18]. Drawing upon the DVC, we argue that SMEs should deliberately make strategy embedded in the needs and demands of dynamic markets [13] that support firm's DC to effectively sense, seize and transform all available opportunities in a fast changing business environment [96], [106]. In the context of SMEs, we posit that SMEs should practice mixing strategy for innovations with DC to be ready to address (new) customer needs, target right markets (new and old ones), and manage their stakeholders accordingly [35], [106], [114]. Therefore, drawing upon both RBV and DCV, we posit that SMEs' strategic resources namely TMT-shared leadership and marketoriented culture act on DC-i.e., innovation capabilities-and that in turn enhances firm performance [25], [27].

\section{B. TMT-Shared Leadership and Market-Oriented Culture}

TMT-shared leadership is a cooperative communal process involving interactions of multiple actors [109] wherein leadership is carried out by the team in setting organizational goals, priorities, task behaviors, and group maintenance [12], [32]. Market-oriented culture, on the other hand, aims at creating higher customer value [1] through organizational practices that emphasizes market-oriented values, norms, market-associated norms, and actions [50]. TMT-shared leadership favors collective decision making for generating strategic alternatives and reconciling paradoxes [73]. TMT-shared leadership being a team process and most suited for SMEs as there is natural linkage between leadership and entrepreneurship [2], [19], [32]. Therefore, TMT-shared leadership is responsible for installing and leveraging firm market-oriented culture [78] through exploratory and exploitative innovation [73] for superior firm performance. Furthermore, we posit that TMT-shared leadership creates conditions to practice market-oriented culture with twin objectives of satisfying customer needs and close eyes over the competitors' offerings, through shifting between roles of leader and follower [30], [100] so as to create interdependence among team members [80]. Thus, we predict:

Hypothesis 1 (H1): TMT-shared leadership influences marketoriented culture.

\section{TMT-Shared Leadership and Firm Innovation Capability}

TMT-shared leadership is multifaceted, adaptive progression that comprises uninterrupted leading and following interfaces [28] that has distinctive impact on the performance of team 
[111] and a useful predictor of team effectiveness [88]. In other words, shared leadership is a kind of participative leadership [89] and is inextricably linked with the innovation and the creativity [65]. On the other hand, innovation capability is an intangible asset that firms exploit it to produce innovations continually [97] wherein firms transform ideas and knowledge into processes, services, and products for the benefits of the organization [69], [81], [95].

We argue that TMT-shared leadership provides psychological climate for the team members to lead themselves [20] and share responsibilities with each other [115] and such a kind of leadership push coworkers to engage in innovative job behaviors, experimentations, and out-of-box thinking [67]. Such a kind of leadership develops competencies in the coworkers, who are future focused as well as internally programmed to develop as well as use new technologies for process and product innovation [62], [82], [92]. Therefore, the TMT allocates larger amount of valuable strategic assets for innovation-related activities and adoption of innovation-oriented strategies [7], [53], [103], [105] to enhance the organization's capability to compete with the competitors. We posit that innovation capability acts as a catalyst for firms to cultivate innovations uninterruptedly, in their processes and/or products, to respond to the dynamic markets [64], [102], [104] and beat competitions from their rivals in the marketplace. Therefore, we predict:

Hypothesis 2 (H2): TMT-shared leadership influences firm innovation capability.

\section{Market-Oriented Culture and Firm Innovation Capability}

Market-oriented culture keeps organizations close to the marketplace [79] through its strong client focus together with evaluation of strengths and weaknesses of enterprise [59, p. 29]. Moreover, market-oriented culture emphasizes upon incorporation of the voice of the customers into organization's strategies, cultures, and behaviors [61] to achieve competitive advantage [94]. Therefore, market-oriented culture has been found to positively impact new product performance [77] and, to reap its benefits, managers need to complement it with appropriate marketing performance measurement metrics but its level and focus vary across small-to-large organizations [38]. Furthermore, we argue that market-oriented culture and firm innovation capabilities are inextricably intertwined [85], [90] as the former positively influence firms innovation capabilities [9], [85] and also necessary for innovation-related efforts in the organization [60], [72]. Therefore, we posit that market-oriented culture increases firm's ability to collect and use knowledge about competitors, competitions, and customers, and that in turn results in market-based innovation in products and/or processes [43], [67], [84]. In other words, market-oriented culture enhances firms' exploratory capabilities to exploit knowledge through innovations, resulting in higher business performance [34], [74]. Therefore, we propose:

Hypothesis 3 (H3): Market-oriented culture influences firm innovation capability.

\section{E. Firm Innovation Capability and Firm Performance}

Firm innovation capability helps companies to cope effectively in dynamic business environments through the development of products and/or processes for enhanced firm performance [76], [101]. The TMT of entrepreneurial enterprise continuously engage in using all the available resources at its disposal to develop firm innovation capability to enhance firm performance through new product lines/production methods, entering new markets, and discover new sources of supply of raw materials [46]. Therefore, we argue that innovation capability is firm's DC that are leveraged to develop cutting-edge knowledge intensive products to satisfy customers [15], [37], [110] and enhance firm performance. Furthermore, firm performance depends on leveraging firm innovation capability to create new processes, services, and products to increase barriers against imitations by rivals in the dynamic markets [26], [29]. Moreover, firms with commitment to continuous innovation is likely to reduce costs of production and/or services, retaining old customers along with attracting new customers and that in turn results in increased market and financial performance [26], [29]. However, Simpson et al. [101] suggest that firm innovation orientation in the early phase has a negative side namely decrement in short-term profit, market risk, stressed and dissatisfied human capital and substantial investment expenses, but it benefits firms as innovation orientation improves the long-term performance of firms. Therefore, we hypothesize:

Hypothesis 4 (H4): Firm innovation capability influences firm
performance.

\section{F. Shared Leadership and Firm Performance}

Shared leadership in a TMT setting is carried out by team as a whole wherein there is distribution of leadership tasks among TMT members [12], [73]. Shared leadership encourages functional conflict and inclusive decision making within the TMT [73]. Extant literature suggest that TMT-shared leadership is critical for firm performance [32], [45], [48], [73]. The linkages between TMT-shared leadership and objective performance results make SMEs a perfect context [32], as TMT-shared leadership behavior relate to interdependence among team members [12], [73]. We argue that the shared leadership facilitates the process of developing shared strategic cognition and this shared cognition in the TMT influences firm performance [32], [48]. Therefore, we predict:

Hypothesis 5 (H5): TMT-shared leadership influences firm performance.

\section{G. Mediating Role of Market-Oriented Culture}

Several studies suggest that TMT-shared leadership impacts firm innovation capability [82], [92]. TMT-shared leadership aims at developing future-focused competencies among their employees toward the use of new technologies for innovation in processes, products, and/or services for the benefits of the enterprises [82], [92]. Furthermore, TMT-shared leadership creates conditions for innovations to flourish through allocation of invaluable strategic assets to innovation-related activities 
aimed at new process/service/product development and adoption of innovation-oriented approaches [53], [105] necessary to increase firm's ability to compete in the dynamic markets. As a result, firm innovation capability acts as a catalyst to promote process/product/service innovations repeatedly for firm to respond to the dynamic markets [104].

Extant literature suggests that TMT-shared leadership positively influences market-oriented culture [30], [73]. TMT-shared leadership, through shifting between roles of leader and follower, builds environments to practice market-oriented culture with twin aims of customer satisfaction and also to keep close eyes over the competitors' offerings [30] so as to create interdependence among team members [80]. Similarly, market-oriented culture results in incorporating customers' voice into strategies, cultures, and behaviors of organization [61] for the purpose of making positive influence on new product development and performance [77]. As such, market-oriented culture prevails upon team members to constantly innovate products and services for customer satisfaction and ensuring tough competition for rivals [42], [54]. Therefore, we predict:

Hypothesis 6(H6): Market-oriented culture mediates between TMTshared leadership and firm innovation capability.

\section{H. Mediation Role of Firm Innovation Capability}

The relationships of market-oriented culture-firm innovation capability performance are not always linear but can be nonlinear too, as market-oriented culture indirectly through firm innovation capability influences SME performance [51], [57]. The market-oriented culture facilitates culture of innovation and continuous improvement in organizational processes and systems for developing a distinctive firm's innovation capabilities relative to the market competition [61]. We posit that market culture influences innovation capabilities to let the firms to survive and succeed better than their competitors [68] and that, in turn, results in enhanced firm performance [75], [91] (De Luca \& Atuahene-Gima, 2007). Furthermore, several other research works suggested that firm innovation capability is positively associated with the performance of organization [9], [11], [22], [52] (Carmen \& Jose, 2008) and can be effectively leveraged by firms. Therefore, we propose:

\section{Hypothesis 7(H7): Firm innovation capability mediates between} market-oriented culture and firm performance.

We contemplate that leveraging firm innovation capability to achieve stated goals is a function of intentions and abilities of leaders and members of organizations. Such an organizational atmosphere is best achieved through shared leadership, as it is a significant and positive predictor of performance and effectiveness of the workgroup [80], [117]. Shared leadership arises from willingness of leader to pass on the leadership authority and power to the team members [49] and readiness of TMT team to agree to take the responsibilities and opportunities to concurrently lead and follow their colleagues [28]. We posit that TMT-shared leadership predicts performance of team members [80], [117] and variance in performance across academic and organizational contexts [32], [80], [111], especially when team

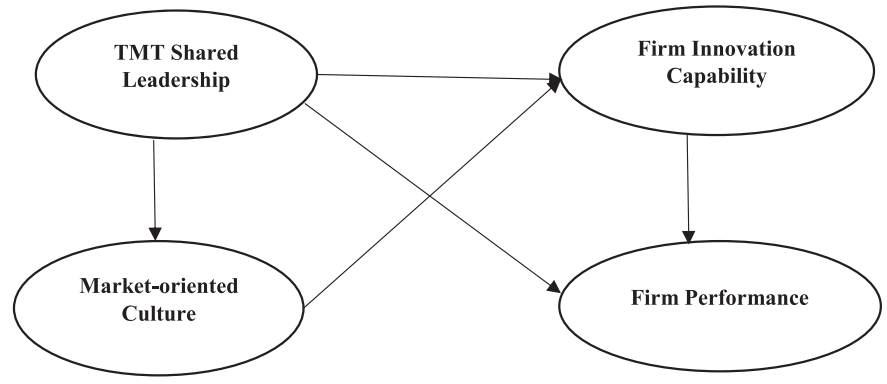

Fig. 1. Proposed research framework.

as a unit possess superior task-related competencies [16]. Hence, we hypothesize that:

Hypothesis 8 (H8): Firm innovation capability mediates between TMT-shared leadership and firm performance.

\section{Proposed Research Framework}

Based on the extant research literature and hypotheses framed, we propose a research framework in Fig. 1 to be examined empirically in this article.

\section{METHODS}

\section{A. Data and Sample}

We conducted this study on 336 SMEs belonging to the service and the manufacturing sectors in Abu Dhabi, the United Arab Emirates. Initially, we approached 538 SMEs to participate but only 489 of them agreed to take part in our study but 336 valid filled-in survey questionnaires returned from the dyad - the CEOs/TMT and the production/operations manager-were used to examine hypotheses of our study. The CEOs/TMT responded to the shared leadership and the firm performance questionnaires. The production/operations manager responded to survey questionnaire items for the market-oriented culture and firm innovation capability. All the items in the survey questionnaires were rated on seven-point Likert scale (wherein $1=$ low and 7 = high) by the CEOs/TMT and the production/operations managers. Before actual data collection, we pilot tested the measuring instruments on CEOs/TMT-Production/Operations Managers dyad in 23 service and manufacturing sectors SMEs in Abu Dhabi, the UAE, to test for ambiguity, if any, in the framing of the items using 10-point rating scale (wherein $1=$ highly ambiguous and $10=$ highly unambiguous). All 28 items of measuring instruments for shared leadership, market-oriented culture, firm innovation capability, and firm performance were found to be unambiguous with some rewording of the items. Since the original measuring instruments were in English and majority of the respondents were fluent in Arabic reading and writing, we followed Brislin [8] for translation-back translation procedure-from English to Arabic and back to English.

In this article, we followed Latan [63] to test for the nonresponse bias and the common method bias to understand about the characteristics of the sample. We used the independent t-test to between the early respondents and the late respondents to 
TABLE I

NONRESPONSE BIAS TEST

\begin{tabular}{|l|c|c|}
\hline \multicolumn{1}{|c|}{ Construct } & Sig. Levene's Test & Sig. t-test for Equality of Means \\
\hline Shared Leadership (SL) & 0.357 & 0.761 \\
\hline Market Culture (MC) & 0.321 & 0.792 \\
\hline Firm Innovation Capability (FIC) & 0.232 & 0.525 \\
\hline Firm Performance (FPERF) & 0.216 & 0.188 \\
\hline
\end{tabular}

TABLE II

ORGANIZATION AND SAMPLE DETAILS

\begin{tabular}{|c|c|c|c|c|c|}
\hline Variable(s) & Number & Percentage & Variable(s) & Number & Percentage \\
\hline $\begin{array}{l}\text { Gender }(\text { CEOs/TMT) } \\
\text { Male } \\
\text { Female }\end{array}$ & $\begin{array}{c}248 \\
88\end{array}$ & $\begin{array}{l}73.81 \\
26.19\end{array}$ & $\begin{array}{l}\text { Age }(\text { CEOs/TMT }) \\
25-35 \text { Years } \\
36-45 \text { Years } \\
46-55 \text { Years } \\
55 \text { Years and above }\end{array}$ & $\begin{array}{c}52 \\
97 \\
123 \\
64\end{array}$ & $\begin{array}{l}15.48 \\
28.87 \\
36.60 \\
19.05\end{array}$ \\
\hline $\begin{array}{l}\text { Gender (production/operations } \\
\text { manager) } \\
\text { Male } \\
\text { Female }\end{array}$ & $\begin{array}{l}211 \\
125\end{array}$ & $\begin{array}{l}62.80 \\
37.20\end{array}$ & $\begin{array}{l}\text { Age (production/operations } \\
\text { manager) } \\
25-35 \text { Years } \\
36-45 \text { Years } \\
46-50 \text { Years } \\
51 \text { Years and above }\end{array}$ & $\begin{array}{c}59 \\
94 \\
119 \\
64\end{array}$ & $\begin{array}{l}17.56 \\
27.98 \\
35.41 \\
19.05\end{array}$ \\
\hline $\begin{array}{l}\text { Educational qualification } \\
\text { (CEOs/TMT) } \\
\text { High school } \\
\text { Diploma } \\
\text { Bachelor degree } \\
\text { Master degree }\end{array}$ & $\begin{array}{c}21 \\
41 \\
207 \\
67\end{array}$ & $\begin{array}{c}6.25 \\
12.20 \\
61.61 \\
19.94\end{array}$ & $\begin{array}{l}\text { Educational qualification } \\
\text { (production/operations } \\
\text { manager) } \\
\text { High school } \\
\text { Diploma } \\
\text { Bachelor degree } \\
\text { Master degree }\end{array}$ & $\begin{array}{c}2 \\
16 \\
231 \\
87\end{array}$ & $\begin{array}{c}0.60 \\
4.76 \\
68.75 \\
25.89\end{array}$ \\
\hline $\begin{array}{l}\text { SMEs (Industry Type) } \\
\text { Cargo and shipping } \\
\text { Chemical products } \\
\text { Constructions } \\
\text { Electrical appliances } \\
\text { Fashion \& beauty } \\
\text { Food packaging } \\
\text { Logistics } \\
\text { Perfume manufacturing } \\
\text { Tourism and hospitality software }\end{array}$ & $\begin{array}{l}43 \\
38 \\
36 \\
44 \\
19 \\
33 \\
41 \\
26 \\
38 \\
18\end{array}$ & $\begin{array}{c}12.80 \\
11.31 \\
10.71 \\
13.10 \\
5.65 \\
9.82 \\
12.20 \\
7.74 \\
11.31 \\
5.36\end{array}$ & $\begin{array}{l}\text { Total number of employees } \\
\text { in SMEs } \\
100-200 \\
201-300 \\
301-400 \\
401-500\end{array}$ & $\begin{array}{c}12 \\
32 \\
158 \\
134\end{array}$ & $\begin{array}{c}3.57 \\
9.52 \\
47.02 \\
39.89\end{array}$ \\
\hline $\begin{array}{l}\text { Year of establishment } \\
\geq \text { Year 2007-2010 } \\
\text { Year 2011-2013 } \\
\text { Year 2014-2015 }\end{array}$ & $\begin{array}{c}166 \\
124 \\
46\end{array}$ & $\begin{array}{c}49.41 \\
36.9 \\
13.69\end{array}$ & - & - & - \\
\hline
\end{tabular}

confirm that the respondents represent the characteristics of the population from where they were picked in this study and Table I indicates no significant difference as the significance values were $>0.05$. Thus, our dataset does not have nonresponse biases and the results obtained from this dataset can be generalized to larger population due to the same sampling weight [6]. Afterward, we used average full collinearity VIF [58] to examine the dataset for the common method biases, if any, wherein the
AFVIF was obtained $1.968<3.3$. This result illustrates that common-method bias is absent from the dataset. Finally, we used Cochran's sample size formula as per recommendations of Bartlett et al. [5] to test for the minimum sample size necessary to carry out this study. It was found that minimum 209 sample (wherein margin of error $=0.03$; alpha value $=0.01$ ) as per Bartlett et al. [5] is good enough to examine the hypotheses and the sample size in this study was 336 . 
TABLE III

TEST For CONVERGENT VALIDITY

\begin{tabular}{|c|c|c|c|c|c|}
\hline Constructs & Indicators & $\begin{array}{l}\text { Std } \\
\text { Loading }\end{array}$ & $\begin{array}{l}\text { Cronbach } \\
\text { Alfa }\end{array}$ & SCR & AVE \\
\hline \multirow{9}{*}{$\begin{array}{l}\text { Shared } \\
\text { leadership }\end{array}$} & & & 0.914 & 0.905 & 0.621 \\
\hline & Implementation new businesses (SL1) & 0.716 & & & \\
\hline & Setting strategic objectives (SL2) & 0.666 & & & \\
\hline & Planning about major operations (SL3) & 0.713 & & & \\
\hline & High expectations in the work (SL4) & 0.702 & & & \\
\hline & Setting common goals (SL5) & 0.799 & & & \\
\hline & Making critical decisions (SL6) & 0.777 & & & \\
\hline & Business performance evaluation (SL7) & 0.806 & & & \\
\hline & Encouraging each other to cooperate (SL8) & 0.707 & & & \\
\hline \multirow{7}{*}{$\begin{array}{l}\text { Market-oriented } \\
\text { culture }\end{array}$} & & & 0.870 & 0.870 & 0.527 \\
\hline & People are competitive and result orientated (MC1) & 0.710 & & & \\
\hline & No-nonsense, aggressive, results-orientated focus (MC2) & 0.718 & & & \\
\hline & Hard-driving competitiveness, high demands and achievement (MC3) & 0.757 & & & \\
\hline & Aggressiveness and winning are common mantras (MC4) & 0.738 & & & \\
\hline & Hitting stretched targets and winning in the marketplace (MC5) & 0.729 & & & \\
\hline & Competitive market leadership (MC6) & 0.703 & & & \\
\hline \multirow{6}{*}{$\begin{array}{l}\text { Firm innovation } \\
\text { capability }\end{array}$} & & & 0.868 & 0.934 & 0.569 \\
\hline & First to market new products/services (FIC1) & 0.816 & & & \\
\hline & Frequent trying out of new ideas (FIC2) & 0.730 & & & \\
\hline & Seeking out new ways to do things (FIC3) & 0.747 & & & \\
\hline & Creative in methods of operations (FIC4) & 0.743 & & & \\
\hline & Increased in new product/service in last three years (FIC5) & 0.733 & & & \\
\hline \multirow{11}{*}{$\begin{array}{l}\text { Firm } \\
\text { performance }\end{array}$} & Financial performance (FINPERF) & & 0.874 & 0.894 & 0.631 \\
\hline & Customer retention (FINPERF1) & 0.717 & & & \\
\hline & Sales growth (FINPERF2) & 0.714 & & & \\
\hline & Profitability (FINPERF3) & 0.707 & & & \\
\hline & Return on investment (FINPERF4) & 0.836 & & & \\
\hline & Overall financial performance (FINPERF5) & 0.966 & & & \\
\hline & Market performance (MKTPERF) & & 0.802 & 0.853 & 0.593 \\
\hline & Entering new markets quickly than competitors (MKTPERF1) & 0.729 & & & \\
\hline & Introducing new product/services faster than competitors (MKTPERF2) & 0.762 & & & \\
\hline & Success rate of new product/services (MKTPERF3) & 0.812 & & & \\
\hline & Market share as compared to the competitors (MKTPERF4) & 0.774 & & & \\
\hline
\end{tabular}

Table II shows that SMEs in this study were from service and manufacturing sectors namely, chemical products, cargo and shipping, constructions, electrical appliances, tourism and hospitality, logistics, information technology, perfume manufacturing, food packaging, and fashion and beauty in Abu Dhabi, the UAE. The respondents in the CEOs/TMT bracket had $73.81 \%$ male and $26.19 \%$ female, and the production/operations mangers comprised $62.80 \%$ male and $37.20 \%$ female. About $65 \%$ of the CEOs/TMTs and $63 \%$ of the production/operations managers were in the age bracket 36-56 years. Furthermore, about $81 \%$ of the CEOs/TMT and $94 \%$ of the production/operations managers had minimum bachelor level of education in arts, science and technology, engineering, and management disciplines. Finally, about $97 \%$ of SMEs had 200-500 employee counts during the time of the study.

\section{B. Variables}

1) Shared Leadership: It had eight items adopted from Mihalache et al. [73]. The sample items include the top management in my organization collectively "sets strategic objectives," "make critical decision," and "evaluate business performance." The Cronbach alpha was 0.914 (see Table III). Confirmatory factor analysis reveals satisfactory data fit $(\chi 2 / d f=1.543, p<$ 0.001; $\mathrm{CFI}=0.991 ; \mathrm{TLI}=934 ; \mathrm{SRMR}=0.030 ; \mathrm{RMSEA}=$ $0.059)$ and they all were in the range.

2) Market-Oriented Culture: We adopted six items subscale of market culture of Cameron and Quin [10] in this article. The sample items includes "competitive market leadership key to winning in the markets and beating the competition." The Cronbach alpha was 0.870 (see Table III). The goodness-of-fit indices of market-oriented culture scale $(\chi 2 / d f=1.738, p<$ 0.001 ; $\mathrm{TLI}=0.968 ; \mathrm{SRMR}=0.033$, RMSEA $=0.069)$ were in the satisfactory range.

3) Firm Innovation Capability: It had five items adopted from [9]. The sample items included were our company frequently tries out "new ideas," "new way of doing things," etc. The goodness-of-fit indices were $(\chi 2 / d f=1.149, p<0.001$; $\mathrm{TLI}=0.986 ;$ SRMR $=0.021 ; \mathrm{RMSEA}=0.031)$ in acceptable range and Cronbach alpha coefficient was 0.868 (see Table III).

4) Firm Performance: It had two subscales with five and four items each for financial and market performance was adopted 
TABLE IV

TEST FOR DISCRIMINANT VALIDITY

\begin{tabular}{|l|l|l|l|l|l|l|l|l|l|}
\hline & & Mean & SD & $\mathbf{1}$ & $\mathbf{2}$ & $\mathbf{3}$ & $\mathbf{4}$ & $\mathbf{5}$ & $\mathbf{6}$ \\
\hline 1 & Shared leadership (SL) & 5.71 & 0.747 & $\mathbf{0 . 7 8 8}$ & & & & & \\
\hline 2 & Market-oriented culture (MOC) & 5.74 & 0.703 & $0.642^{* *}$ & $\mathbf{0 . 7 2 6}$ & & & & \\
\hline 3 & Firm innovation capability (FIC) & 5.57 & 0.781 & $0.661^{* *}$ & $0.548^{* *}$ & $\mathbf{0 . 7 5 4}$ & & & \\
\hline 4 & Financial performance (FINPERF) & 5.58 & 0.801 & $0.552^{* *}$ & $0.476^{* *}$ & $0.435^{* *}$ & $\mathbf{0 . 7 9 4}$ & & \\
\hline 5 & Market performance (MKTPERF) & 5.66 & 0.723 & $0.581^{* *}$ & $0.439^{* *}$ & $0.425^{* *}$ & $0.453^{* *}$ & $\mathbf{0 . 7 5 1}$ & \\
\hline 6 & Firm performance (FPERF) & 5.63 & 0.779 & $0.571^{* *}$ & $0.441^{* *}$ & $0.428^{* *}$ & $0.445^{* *}$ & $0.451^{* *}$ & $\mathbf{0 . 7 8 4}$ \\
\hline
\end{tabular}

Note: the diagonal bold italic values in this table represent square roots of AVE.

TABLE V

TESTING FOR DIRECT EFFECT

\begin{tabular}{|l|l|l|l|l|l|}
\hline Direct effect & $\begin{array}{l}\text { Standardized } \\
\text { direct effect }\end{array}$ & Standard error & t value & Sig. level & Decision \\
\hline MOC<---SL & 0.569 & 0.049 & 8.647 & $p<0.001$ & H1 is Accepted \\
\hline FIC<---SL & 0.545 & 0.047 & 7.415 & $p<0.001$ & H2 is Accepted \\
\hline FIC<---MOC & 0.167 & 0.063 & 2.276 & $p<0.036$ & H3 is Accepted \\
\hline FPERF<---FIC & 0.279 & 0.129 & 3.236 & $p<0.002$ & H4 is Accepted \\
\hline FPERF<---SL & 0.344 & 0.082 & 3.995 & $p<0.002$ & H5 is Accepted \\
\hline
\end{tabular}

Wherein $S L=$ shared leadership, $M O C=$ market-oriented culture, FIC = firm innovation capability, FPERF = firm performance .

from [108] and [112]. The sample items include my firm has performed better than competitors in last three years in terms of "customer retention," "return of investment," "entering new markets," etc. The Cronbach alpha was 0.864 as in Table III. The goodness-of-fit indices of the scale were $(\chi 2 / d f=1.409, p$ $<0.001 ;$ TLI $=0.958 ;$ SRMR $=0.056$; RMSEA $=0.051)$ in the acceptable range.

\section{RESULTS}

\section{A. Measurement Validation}

We used Cronbach alpha to assess reliability of all four measuring instruments [44] and they ranged from 0.864 to 0.914 (see Table III). Furthermore, we measured convergent and divergent validity of the measuring instruments. Here, the individual item should load on their intended constructs with standardized loadings in the range of $>0.5$ to $\geq 0.7$, scale composite reliability (SCR) should be $>0.7$, and average variance extracted (AVE) should be $>0.5$ [36]. Table III suggests that all four measuring instruments had high convergent validity [36], as the standardized loading of individual item on their intended construct was obtained in the range of $\geq 0.666$ to 0.966 with $\mathrm{SCR} \geq 0.870$ to $0.934, \mathrm{AVE} \geq 0.527$ to 0.621 . Therefore, it explains that items of the scale elucidate higher variance than the error terms and suggest that the measurement instruments were unidimensional [36]. Furthermore, we examined discriminant validity of the constructs wherein we found that the standardized loading of the items of scale ranged from $\geq 0.666$ to 0.966 and the square root of the AVE was greater than the correlations amongst the constructs. Hence, Tables III and IV together suggest that constructs in this study have discriminant validity as per the recommendations of [33].

\section{B. Structural Model}

We used the structural equation model (SEM) to test the hypotheses. The results for the "testing for direct effect" and the "testing for indirect effect" are presented in Tables V and VI, respectively.

1) Testing for Direct Effect: Table V shows that $\mathrm{H} 1$ $[\mathrm{MOC}<-\mathrm{SL}] ; \mathrm{H} 2 \quad[\mathrm{FIC}<-\mathrm{SL}] ; \mathrm{H} 3 \quad[\mathrm{FIC}<-\mathrm{MOC}] ; \mathrm{H} 4$ [FPERF $<-$ FIC] ; and H5 [FPERF $<-\mathrm{SL}]$ are supported $(\beta=$ $0.569 ; t=8.647, p<0.001) ;(\beta=.545 ; t=7.415, p<0.001) ;$ $(\beta=0.167, t=2.276, p<0.036) ;(\beta=0.279 ; t=3.236, p<$ $0.002)$; and $(\beta=0.344 ; t=3.995, p<0.002)$, respectively. In other words, TMT-shared leadership positively influences market-oriented culture (H1), firm innovation capability (H2), and firm performance (H5). On the other hand, market-oriented culture affects firm innovation capability (H3) and firm innovation capability to influence firm performance (H4).

2) Testing for Mediating Effects: We used bootstrapping statistics while performing the SEM, as recommended by [118], to test for the hypotheses related to the mediating effects among the constructs in the proposed framework of this article. Table VI shows that $\mathrm{H} 6 \quad[\mathrm{FIC}<-\mathrm{MOC}<-\mathrm{SL}], \quad \mathrm{H} 7 \quad[\mathrm{FPERF}<-$ $\mathrm{FIC}<-\mathrm{MOC}]$, and $\mathrm{H} 8[\mathrm{FPERF}<-\mathrm{FIC}<-\mathrm{SL}]$ are supported 
TABLE VI

TESTING FOR INDIRECT EFFECT

\begin{tabular}{|l|l|l|l|}
\hline Indirect effect & $\begin{array}{l}\text { Standardized } \\
\text { indirect effect }\end{array}$ & Sig. level & Decision \\
\hline FIC $<---M O C<---S L$ & $\beta=0.095$ & $p<0.036$ & H6 is Accepted \\
\hline FPERF $<---$ FIC $<---M O C$ & $\beta=0.047$ & $p<0.037$ & H7 is Accepted \\
\hline FPERF $<--$ FIC $<--$ SL & $\beta=0.178$ & $p<0.002$ & H8 is Accepted \\
\hline
\end{tabular}

Wherein $S L=$ shared leadership, $M C=$ market-oriented culture, FIC $=$ firm innovation capability, FPERF $=$ firm performance.

$(\beta=0.095, p<0.036),(\beta=0.047, p<.037)$, and $(\beta=0.178$, $p<.002)$ respectively. Therefore, this article suggests that market-oriented culture mediates the relationships of TMTshared leadership and firm innovation capability (H6). Similarly, results in Table VI suggest that firm innovation capability mediates the influence of market-oriented culture and firm performance (H7), and the influence of TMT-shared leadership and firm performance (H8).

\section{DISCUSSION AND CONCLUSION}

Important literature in the field suggest for how TMT-shared leadership affects market-oriented culture to satisfy customer needs and keep close eyes over the competitors' offerings, through shifting between roles of leader and follower [30], [73], [100]. Furthermore, past studies indicate about the critical role of market-oriented culture vis-à-vis firm innovation capability [74], [85] as the market-oriented culture increases organizational ability to collect and use knowledge about competitors, competitions, and customers to increase firm innovation capability [84] for enhanced firm performance. In this article, we empirically examined five direct and three indirect hypotheses and they were accepted. Therefore, the findings of this article support previous studies that TMT-shared leadership influences market-oriented culture [73], [100], firm innovation capability [82], [92], and firm performance [48], [73]. Similarly, this article supported past studies that market-oriented culture influences firm innovation capability [85], [90] and firm innovation capability to influence firm performance [26], [29]. In addition, we found that firm innovation capability mediates on to the influence of TMT-shared leadership and market-oriented culture on firm performance. Last, but not the least, we also found market-oriented culture to mediate on to the linkage between TMT-shared leadership and firm performance. Overall, the findings of this article make significant theoretical and practical contributions.

\section{A. Theoretical Contributions}

This article offers three theoretical contributions. First, our study advances the usage of both RBV and DCV lenses to understand how firm innovation capability helps enhance SMEs' performance in the UAE context. The finding of the article suggests that SMEs should enhance their DC (i.e., innovation capabilities) in a manner that they become able to effectively sense, seize, and transform all available opportunities in their dynamic markets for enhanced firm performance [106]. This article also suggests that TMT-shared leadership and market-oriented culture act as strategic resources [21] that SMEs should leverage to increase their innovation capabilities - the DC - for enhanced firm performance [4], [86], [106]. Moreover, we suggest that SMEs should leverage their strategic resources-TMT-shared leadership and market-oriented culture-in a manner to enhance their dynamic innovation capabilities to address (new) customer needs, target the right markets (new and old ones), and manage their stakeholders accordingly [106].

Second, previous studies suggested that TMT-shared leadership influences market-oriented culture [30] and firm innovation capability [82], [92] and market-oriented culture predicts firm innovation capability [9], [85]. Based on the findings of this article, we suggest that TMT-shared leadership also indirectly influences firm innovation capability through market-oriented culture. In other words, TMT-shared leadership symbolizes shifting the roles of leader and follower among themselves for creating interdependence among team members [80] so as to incorporate customers' voice into strategies, cultures, and behaviors of organization [61] for the purpose of making positive influence on new product development and performance [77]. Therefore, this article fill in the gaps in the available literature on how to enhance firm innovation capability for sustainable competitive advantage.

Thirdly, this article extends the literature on firm innovation capability vis-à-vis firm performance. Extant literature suggest that firm innovation capability helps enterprises to cope effectively in dynamic markets through innovation in processes, products, and/or services to keep customers happy and satisfied and enhance the firm performance [23], [98], [99]. Several research works also note that innovation capability of firm increases barriers against imitations by rivals in the business environment [26], [29]. This article extends the findings of the previous studies [26], [29] wherein we suggest that TMT-shared leadership and market-oriented culture boost firm innovation capability and that drives superior SMEs' performance. We suggest that firm innovation capability cannot exist in isolation but it requires strategic resources namely, TMT-shared leadership and market-oriented culture as springboard to drive enhanced firm performance.

\section{B. Practical Implications}

This article offers several practical implications as well. First, SMEs play a critical role in the growth of the country through their quick and flexible decision making, entrepreneurial dynamism, flexibility, motivation, etc. SMEs in the UAE contribute 
$30 \%$ of the GDP and entrepreneurial ventures are highly valued by the UAE society as one of the best career choices [40]. Therefore, while extending the findings of this article, we suggest that governmental agencies responsible for supporting SMEs should provide training to the entrepreneurs on developing shared leadership skills to boost the innovation capabilities of the entrepreneurial ventures to stay competitive in the markets. Second, the UAE is ranked 26th among 139 countries and 1st among the countries in the Middle Eastern and North Africa on Networked Readiness Index [41]. That speaks volume about UAE government intentions to leverage all opportunities that information and communications technology (ICT) offers to the SMEs. However, the optimum exploit of opportunities offered by ICT depends upon organizational culture namely, beliefs, values and norms in practice at workplace in the SMEs. This article suggests that SMEs should install market-oriented culture to exploit available opportunities that ICT offers especially to develop and sustain firm innovation capability. Third, this article suggests that SMEs innovation capability drives firm performance-the market and the financial performance. Therefore, we suggest that SMEs should be future focused in how to develop and use new technologies for process and product innovation aimed at achieving competitive advantage necessary for creating and sustaining superior performance of SMEs in the dynamic market.

\section{Limitations and Direction for Future Research}

Like any other study in the management science disciplines, this article is not without limitations. Thus, we present the limitations of this article with suggestions and direction for future research. First, we relied on the perceptual measures of the constructs. As a result, we suggest that future research should use both objective and subjective measures, especially for the constructs of firm performance and firm innovation capability, for better generalization of the results. Second, we studied team and firm level constructs in this research. We suggest that future research should include individual level construct(s) along with group/team and firm level construct(s) to provide a much broader picture. Third, we examined the conceptual research model on SMEs in the UAE context. Therefore, future research should extend our research framework outside the UAE to contribute to theory development.

\section{REFERENCES}

[1] S. Agarwal, M. K. Erramilli, and C. S. Dev, "Market orientation and performance as service firms: Role of innovation," J. Serv. Market., vol. 17 , no. 1, pp. 68-82, 2003.

[2] N. Athanassiou and D. Nigh, "The impact of US company internationalization on top management team advice networks: A tacit knowledge perspective," Strategic Manage. J., vol. 20, no. 1, pp. 83-92, 1999.

[3] D. B. Audretsch and M. Keilbach, "The theory of knowledge spillover entrepreneurship," J. Manage. Stud., vol. 44, no. 7, 1242-1254, 2007.

[4] J. B. Barney, "Is the resource-based 'view' a useful perspective for strategic management research? Yes," Acad. Manage. Rev., vol. 26, no. 1, pp. 41-57, 2001.

[5] J. E. Bartlett, J. W. Kotrilk, and C. C. Higgins, "Organizational research: Determining appropriate sample size in survey research," Inf. Technol. Learn. Perform. J., vol. 19, no. 1, pp. 43-50, 2001.

[6] J.-M. Becker and I. R. Ismail, "Accounting for sampling weights in PLS path modeling: Simulations and empirical examples," Eur. Manage. J., vol. 34, no. 6, pp. 606-617, 2016.
[7] A. M. Biscotti, E. Mafrolla, M. Del Giudice, and E. D'Amico, "CEO turnover and the new leader propensity to open innovation: Agencyresource dependence view and social identity perspective," Manage. Decis., vol. 56, no. 6, pp. 1348-1364, 2018.

[8] R. Brislin, "The wording and translation of research instruments," in Field Methods in Cross-Cultural Research. Cross-Cultural Research and Methodology Series, vol. 8, W. Lonner and J. Berry, Eds. Thousand Oaks, CA, USA: Sage, 1986, pp. 137-164.

[9] R. J. Calantone, S. T. Cavusgil, and Y. Zhao, "Learning orientation, firm innovation capability and firm performance," Ind. Market. Manage., vol. 31, no. 6, pp. 515-524, 2002.

[10] K. S. Cameron and R. E. Quin, Diagnosing and Changing Organizational Culture: Based on the Competing Value Framework. San Francisco, CA, USA: Jossey-Bass, 2006.

[11] C. Camisón and A. Villar-López, "Organizational innovation as an enabler of technological innovation capabilities and firm performance," $J$. Bus. Res., vol. 67, no. 1, pp. 2891-2902, 2014.

[12] J. B. Carson, P. E. Tesluk, and J. A. Marrone, "Shared leadership in teams: An investigation of antecedent conditions and performance," Acad. Manage. J., vol. 50, no. 5, pp. 1217-1234, 2007.

[13] R. Casadesus-Masanell and J. E. Ricart, "From strategy to business models and onto tactics," Long Range Planning, vol. 43, nos. 2/3, pp. 195-215, 2010.

[14] E. Casprini, A. De Massis, A. Di Minin, F. Frattini, and A. Piccaluga, "How family firms execute open innovation strategies: The Loccioni case," J. Knowl. Manage., vol. 21, no. 6, pp. 1459-1485, 2017.

[15] S. Castellano, I. Khelladi, and S. Ivanaj, "Entrepreneurial intensity and firm performance: The role of institutional ambidexterity," IEEE Trans. Eng. Manage., 2019, to be published, doi: 10.1109/TEM.2019.2901500.

[16] C.-Y. (C.) Chiu, B. P. Owens, and P. E. Tesluk, "Initiating and utilizing shared leadership in teams: The role of leader humility, team proactive personality, and team performance capability," J. Appl. Psychol., vol. 101, no. 12, pp. 1705-1720, 2016.

[17] F. Ciampi, V. Cillo, and F. Fiano, "Combining Kohonen maps and prior payment behavior for small enterprise default prediction," Small Bus. Econ., pp. 1-33, 2018. [Online]. Available: https://link.springer.com/ article/10.1007/s11187-018-0117-2

[18] V. Cillo, A. M. Petruzzelli, L. Ardito, and M. Del Giudice, "Understanding sustainable innovation: A systematic literature review," Corporate Soc. Responsibility Environ. Manage., 2019. [Online]. Available: https://doi.org/10.1002/csr.1783

[19] C. C. Cogliser and K. H. Brigham, "The intersection of leadership and entrepreneurship: Mutual lessons to be learned," Leadership Quart., vol. 15, pp. 771-799, 2004

[20] J. F. Cox, C. L. Pearce, and M. L. Perry, "Toward a model of shared leadership and distributed influence in the innovation process," in Shared Leadership: Reframing the Hows and Whys of Leadership, C. L. Pearce and J. A. Conger, Eds. Thousand Oaks, CA, USA: Sage, 2003, pp. 48-76.

[21] T. R. Crook, D. J. Ketchen, J. G. Combs, and S. Y. Todd, "Strategic resources and performance: A meta-analysis," Strategic Manage. J., vol. 29, no. 11, pp. 1141-1154, 2008.

[22] F. Damanpour, R. M. Walker, and C. N. Avellaneda, "Combinative effects of innovation types and organizational performance: A longitudinal study of service organizations," J. Manage. Stud., vol. 46, no. 4, pp. 650-675, 2009.

[23] M. Del Giudice and M. R. Della Peruta, "The impact of IT-based knowledge management systems on internal venturing and innovation: A structural equation modeling approach to corporate performance," $J$. Knowl. Manage., vol. 20, no. 3, pp. 484-498, 2016.

[24] M. Del Giudice and V. Maggioni, "Managerial practices and operative directions of knowledge management within inter-firm networks: A global view," J. Knowl. Manage., vol. 18, no. 5, pp. 841-846, 2014.

[25] M. Del Giudice, M. R. Della Peruta, and V. Maggioni, "A model for the diffusion of knowledge sharing technologies inside private transport companies," J. Knowl. Manage., vol. 19, no. 3, pp. 611-625, 2015.

[26] M. Del Giudice, P. Soto-Acosta, E. Carayannis, and V. Scuotto, "Emerging perspectives on business process management (BPM): IT-based processes and ambidextrous organizations, theory and practice," Bus. Process Manage. J., vol. 24, no. 5, pp. 1070-1076, 2018.

[27] M. R. Della Peruta, M. Del Giudice, R. Lombardi, and P. Soto-Acosta, "Open innovation, product development, and inter-company relationships within regional knowledge clusters," J. Knowl. Econ., vol. 9, no. 2, pp. 680-693, 2016.

[28] D. S. DeRue, "Adaptive leadership theory: Leading and following as a complex adaptive process," Res. Org. Behav., vol. 31, pp. 125-150, 2011. 
[29] L. Dezi, A. Ferraris, A. Papa, and D. Vrontis, "The role of external embeddedness and knowledge management as antecedents of ambidexterity and performances in Italian SMEs," IEEE Trans. Eng. Manage., 2019, to be published. [Online]. Available: https://doi.org/10.1109/TEM.2019. 2916378

[30] W. H. Drath, C. D. McCauley, C. J. Palus, P. M. G. Van Velsor, and J. B. McGuire, "Direction, alignment, commitment: Toward a more integrative ontology of leadership," Leadership Quart., vol. 19, no. 6, pp. 635-653, 2008.

[31] K. M. Eisenhardt and M. Martin, "Dynamic capabilities: What are they?" Strategic Manage. J., vol. 21, nos. 10/11, pp. 1105-1121, 2000.

[32] M. D. Ensley, K. M. Hmieleski, and C. L. Pearce, "The importance of vertical and shared leadership within new venture top management teams: Implications for the performance of startups," Leadership Quart., vol. 17, no. 3, pp. 217-231, 2006.

[33] S. E. Fawcett, C. Wallin, C. Allred, and G. Magnan, "Supply chain information-sharing: Benchmarking a proven path," Benchmarking: Int. J., vol. 16, no. 2, pp. 222-246, 2009.

[34] A. Ferraris, G. Santoro, and V. Scuotto, "Dual relational embeddedness and knowledge transfer in European multinational corporations and subsidiaries," J. Knowl. Manage., 2018. [Online]. Available: https: //doi.org/10.1108/JKM-09-2017-0407

[35] J. Ferreira and C. Fernandes, "Resources and capabilities' effects on firm performance: What are they?" J. Knowl. Manage., vol. 21, no. 5, pp. 1202-1217, 2017.

[36] C. Fornell and D. F. Larcker, "Structural equation models with unobservable variables and measurement error: algebra and statistics," J. Market. Res., vol. 18, no. 3, pp. 382-388, 1981.

[37] J. Frishammar, M. Kurkkio, L. Abrahamsson, and U. Lichtenthaler, "Antecedents and consequences of firms' process innovation capability: A literature review and a conceptual framework," IEEE Trans. Eng. Manage., vol. 59, no. 4, pp. 519-529, Nov. 2012.

[38] J. Fros'en, J. Luoma, M. Jaakkola, H. Tikkanen, and J. Aspara, "What counts versus what can be counted: The complex interplay of market orientation and marketing performance measurement," J. Market., vol. 80, no. 3, 60-78, 2016.

[39] F. Gama, J. Frishammar, and V. Parida, "Idea generation and open innovation in SMEs: When does market-based collaboration pay off most?" Creativity Innov. Manage., vol. 28, no. 1, pp. 113-123, 2018.

[40] The Global Entrepreneurship Monitor Report 2016/2017, GEM, 2017. [Online]. Available: https://www.c4e.org.cy/reports/2017/gem-20162017-global-report-web-version-1486181226.pdf. Retrieved on: Jan. 3, 2018.

[41] The Global Information Technology Report 2016: Innovating in the Digital Economy, GITR, 2017. [Online]. Available: http://www3.weforum. org/docs/GITR2016/WEF_GITR_Full_Report.pdf_Retrieved on: Jan.3, 2018

[42] L. J. Gressgård, "Virtual team collaboration and innovation in organizations," Team Perform. Manage., vol. 17, nos. 1/2, pp. 102-119, 2011.

[43] G. A. Guzman and J. Wilson, "The "soft" dimension of organizational knowledge transfer," J. Knowl. Manage., vol. 9, no. 2, pp. 59-74, 2005.

[44] J. F. Hair, R. E. Anderson, R. L. Tatham, and W. C. Black, Multivariate Data Analysis. Upper Saddle River, NY, USA: Prentice-Hall Int., 1998.

[45] D. C. Hambrick, "Upper echelons theory: An update," Acad. Manage. Rev., vol. 32, no. 2, pp. 334-343, 2007.

[46] R. Hébert and A. Link, "The entrepreneur as innovator," J. Technol. Transfer, vol. 31, no. 5, pp. 589-597, 2006.

[47] C. E. Helfat et al., Dynamic Capabilities: Understanding Strategic Change in Organizations. New York, NY, USA: Wiley, 2009.

[48] K. M. Hmieleski, M. S. Cole, and R. A. Baron, "Shared authentic leadership and new venture performance," J. Manage., vol. 38, no. 5, pp. 1476-1499, 2012.

[49] J. E. Hoch and S. W. Kozlowski, "Leading virtual teams: Hierarchical leadership, structural supports, and shared team leadership," J. Appl. Psychol., vol. 99, no. 3, pp. 390-403, 2014.

[50] C. Homburg and C. Pflesser, "A multiple-layer of market-oriented organizational culture: Measurement issues and performance outcomes," $J$. Market. Res., vol. 37, pp. 449-462, 2000.

[51] J-P. Huhtala, A. Sihvonen, J. Frösén, M. Jaakkola, and H. Tikkanen, "Market orientation, innovation capability and business performance: Insights from the global financial crisis," Baltic J. Manage., vol. 9, no. 2, pp. 134-152, 2015.

[52] G. T. M. Hult, R. F. Hurley, and G. A. Knight, "Innovativeness: Its antecedents and impact on business performance," Ind. Market. Manage., vol. 33, no. 5, pp. 429-438 2004.
[53] S. D. Hunt, Marketing Theory: Foundations, Controversy, Strategy, Resource-Advantage Theory. New York, NY, USA: ME Sharpe, 2010.

[54] J. Kandampully, "Innovation as the core competency of a service organisation: The role of technology, knowledge and networks," Eur. J. Innov. Manage., vol. 5, no. 1, pp. 18-26, 2002.

[55] F. Kellermanns, J. Walter, T. R. Crook, B. Kemmerer, and V. Narayanan, "The resource-based view in entrepreneurship: A content-analytical comparison of researchers' and entrepreneurs' views," J. Small Bus. Manage., vol. 54, no. 1, pp. 26-48, 2016.

[56] Youth and Entrepreneurship in UAE, Khalifa Fund for Enterprise Development, Abu Dhabi, UAE, 2017. [Online]. Available: https://www.khalifafund.ae/SiteAssets/KF/Documents/Youth_and_ entrepreneurship.pdf. Retrieved on: Jan. 3, 2018.

[57] A. Kocak, A. Carsrud, and S. Oflazoglu, "Market, entrepreneurial, and technology orientations: Impact on innovation and firm performance," Manage. Decis., vol. 55, no. 2, pp. 248-270, 2017.

[58] N. Kock, "Common methods bias: A full collinearity assessment method for PLS-SEM," in Partial Least Squares Path Modeling: Basic Concepts, Methodological Issues and Applications, H. Latan, and R. Noonan, Eds. Cham, Switzerland: Springer Int. Publishing, 2017.

[59] P. Kotler and G. Armstrong, Principles of Marketing. Boston, MA, USA: Prentice-Hall, 2011.

[60] J. Kratzer, D. Meissner, and V. Roud, "Open innovation and company culture: Internal openness makes the difference," Technol. Forecasting Soc. Change, vol. 119, pp. 128-138, 2017.

[61] V. Kumar, E. Jones, R. Venkatesan, and R. P. Leone, "Is market orientation a source of sustainable competitive advantage or simply the cost of competing?" J. Market., vol. 75, no. 1, pp. 16-30, 2011.

[62] K. Kwon and D. Cho, "How transactive memory systems relate to organizational innovation: The mediating role of developmental leadership," J. Knowl. Manage., vol. 20, no. 5, pp. 1025-1044, 2016.

[63] H. Latan, "PLS path modeling in hospitality and tourism research: The golden age and days of future past," in Applying Partial Least Squares in Tourism and Hospitality Research, F. Ali, M. S. Rasoolimanesh, and C. Cobanoglu, Eds. Bingley, U.K.: Emerald, 2018, pp. 53-83.

[64] P. B. Le and H. Lei, "Determinants of innovation capability: The roles of transformational leadership, knowledge sharing, and perceived organizational support," J. Knowl. Manage., vol. 23, no. 3, pp. 527-547, 2019.

[65] H. E. Lin and E. F. McDonough III, "Investigating the role of leadership and organizational culture in fostering innovation ambidexterity," IEEE Trans. Eng. Manage., vol. 58, no. 3, pp. 497-509, Aug. 2011.

[66] S. C. Lonial and R. E. Carter, "The impact of organizational orientations on medium and small firm performance: A resource-based perspective," J. Small Bus. Manage., vol. 53, no. 1, pp. 94-113, 2015.

[67] G. Martín-de Castro, P. López-Sáez, M. Delgado-Verde, M. J. Donate, and F. Guadamillas, "Organizational factors to support knowledge management and innovation," J. Knowl. Manage., vol. 15, no. 6, pp. 890-914, 2011.

[68] M. Matsuo, "Customer orientation, conflict, and innovativeness in Japanese sales departments," J. Bus. Res., vol. 59, no. 2, pp. 242-250, 2006.

[69] A. Mazzelli, A. De Massis, A. M. Petruzzelli, M. Del Giudice, and Z. Khan, "Behind ambidextrous search: The microfoundations of search in family and non-family firms," Long Range Planning, 2019. [Online]. Available: https://doi.org/10.1016/j.lrp.2019.05.002

[70] M. Mazzero, F. Rosati, M. M. Andersen, and J. Li-Ying, "Strategizing for sustainability in a changing world: A dynamic capability approach," in Proc. DTU Sustain Conf., 2015.

[71] D. Meissner and E. G. Carayannis, "Value generation from industryscience linkages in light of targeted open innovation," J. Knowl. Manage., vol. 21, no. 2, pp. 295-307, 2017.

[72] D. Meissner and N. Shmatko, "Integrating professional and academic knowledge: The link between researchers skills and innovation culture," J. Technol. Transfer, pp. 1-17, 2018.

[73] O. R. Mihalache, J. J. Jansen, F. A. Van den Bosch, and H. W. Volberda, "Top management team shared leadership and organizational ambidexterity: A moderated mediation framework," Strategic Entrepreneurship J., vol. 8, no. 2, pp. 128-148, 2014.

[74] D. Monferrer, A. Blesa, and M. Ripollés, "Born globals trough knowledge-based dynamic capabilities and network market orientation," Bus. Res. Quart., vol. 18, no. 1, pp. 18-36, 2015.

[75] N. Morgan and D. Vorhies, "Market orientation, marketing capabilities, and firm performance," Strategic Manage., vol. 30, no. 8, pp. 909-920, 2009. 
[76] J. Mu, "Dynamic capability and firm performance: The role of marketing capability and operations capability," IEEE Trans. Eng. Manage., vol. 64, no. 4, pp. 554-565, Nov. 2017.

[77] S. Najafi-Tavani, H. Sharifi, and Z. Najafi-Tavani, "Market orientation, marketing capability, and new product performance: The moderating role of absorptive capacity," J. Bus. Res., vol. 69, no. 11, pp. 5059-5064, 2016.

[78] J. C. Narver and S. F. Slater, "The effect of a market orientation on business profitability," J. Market., vol. 54, no. 4, pp. 20-35, 1990.

[79] L. V. Ngo and A. O'Cass, "Performance implications of market orientation, marketing resources and marketing capabilities," J. Market. Manage., vol. 28, nos. 1/2, pp. 173-187, 2012.

[80] V. C. Nicolaides et al., The shared leadership of teams: A meta-analysis of proximal, distal, and moderating relationships," Leadership Quart., vol. 25 , no. 5, pp. 923-942, 2014.

[81] H. A. Nold III, "Linking knowledge processes with firm performance: Organizational culture," J. Intell. Capital, vol. 13, no. 1, pp. 16-38, 2012.

[82] A. O'Cass and P. Sok, "Exploring innovation driven value creation in B2B service firms: The roles of the manager, employees, and customers in value creation," J. Bus. Res., vol. 66, no. 8, pp. 1074-1084, 2013.

[83] F. L. Oliva et al., "Innovation in the main Brazilian business sectors: Characteristics, types and comparison of innovation," J. Knowl. Manage., vol. 23, no. 1, pp. 135-175, 2019.

[84] H. E. Ozkaya, C. Droge, G. T. M. Hult, R. Calantone, and E. Ozkaya, "Market orientation, knowledge competence, and innovation," Int. J. Res. Market., vol. 32, no. 3, pp. 309-3018, 2015.

[85] P. Ozturan, A. Ozsomer, and R. Pieters, "The role of market orientation in advertising spending during economic collapse: The case of Turkey in 2001," J. Market. Res., vol. 51, no. 2, pp. 139-152, 2014.

[86] A. Papa, L. Dezi, G. L. Gregori, J. Mueller, and N. Miglietta, "Improving innovation performance through knowledge acquisition: The moderating role of employee retention and human resource management practices," J. Knowl. Manage., 2018. [Online]. Available: https://doi.org/10.1108/ JKM-09-2017-0391

[87] J. Paul, S. Parthasarathy, and P. Gupta, "Exporting challenges of SMEs: A review and future research agenda," J. World Bus., vol. 52, no. 3, pp. 327-342, 2017.

[88] C. L. Pearce and H. P. Sims, "Vertical versus shared leadership as predictors of the effectiveness of change management teams: An examination of aversive, directive, transactional, transformational, and empowering leader behaviors," Group Dyn.: Theory Res. Pract., vol. 6, no. 2, pp. 172197, 2002.

[89] C. L. Pearce, "The future of leadership: Combining vertical and shared leadership to transform knowledge work," Acad. Manage. Executive, vol. 18 , no. 1, pp. 47-57, 2004.

[90] S. Rakthin, R. L. Calantone, and J. F. Wang, "Managing market intelligence: The comparative role of absorptive capacity and market orientation," J. Bus. Res., vol. 69, no. 12, pp. 5569-5577, 2016.

[91] N. Rosenbusch, J. Brinckmann, and A. Bausch, "Is innovation always beneficial? A meta-analysis of the relationship between innovation and performance in SMEs," J. Bus. Venturing, vol. 26, no. 4, pp. 441-457, 2011.

[92] K. Rosing, M. Frese, and A. Bausch, "Explaining the heterogeneity of the leadership innovation relationship: Ambidextrous leadership," Leadership Quart., vol. 22, no. 5, pp. 956-974, 2011.

[93] J. M. Ruiz-Jiménez and M. del Mar Fuentes-Fuentes, "Management capabilities, innovation, and gender diversity in the top management team: An empirical analysis in technology-based SMEs," Bus. Res. Quart., vol. 19, no. 2, pp. 107-121, 2016

[94] S. Šályová, J. Táborecká-Petrovičováa, G. Nedelováa, and J. Ďasoa, "Effect of marketing orientation on business performance: A study from Slovak foodstuff industry," Procedia Econ. Finance, vol. 34, pp. 622-629, 2015.

[95] C. A. Sampaio, J. M. Hernández-Mogollón, and R. G. Rodrigues, "Assessing the relationship between market orientation and business performance in the hotel industry-The mediating role of service quality," $J$. Knowl. Manage., vol. 23, no. 4, pp. 644-663, 2019.

[96] G. Santoro, S. Bresciani, and A. Papa, "Collaborative modes with cultural and creative industries and innovation performance: The moderating role of heterogeneous sources of knowledge and absorptive capacity," Technovation, 2018. [Online]. Available: https://doi.org/10.1016/ j.technovation.2018.06.003
[97] M. Saunila and J. Ukko, "A conceptual framework for the measurement of innovation capability and its effects," Baltic J. Manage., vol. 7, no. 4 , pp. 355-375, 2012.

[98] T. Schoenherr and M. Swink, "The roles of supply chain intelligence and adaptability in new product launch success, Decis. Sci., vol. 46, no. 5, pp. 901-936, 2015.

[99] V. Scuotto, M. Del Giudice, S. Bresciani, and D. Meissner, "Knowledgedriven preferences in informal inbound open innovation modes: An explorative view on small to medium enterprises," J. Knowl. Manage., vol. 21, no. 3, pp. 640-655, 2017.

[100] S. J. Shondrick, J. E. Dinh, and R. G. Lord, "Developments in implicit leadership theory and cognitive science: Applications to improving measurement and understanding alternatives to hierarchical leadership," Leadership Quart., vol. 21, no. 6, pp. 959-978, 2010.

[101] P. M. Simpson, J. A. Siguaw, and C. A. Enz, "Innovation orientation outcomes: The good and the bad," J. Bus. Res., vol. 59, nos. 10/11, pp. 1133-1141, 2006.

[102] S. K. Singh, M. Del Giudice, R. Chierici, and D. Graziano, "Green transformational leadership, green innovation and environmental performance: Role of green human resource management," Technol. Forecasting Soc. Change, 2019, to be published.

[103] S. K. Singh, S. Gupta, D. Busso, and S. Kamboj, "Top management knowledge value, knowledge sharing practices, open innovation and organizational performance," J. Bus. Res., 2019, to be published. [Online]. Available: https://doi.org/10.1016/j.jbusres.2019.04.040

[104] S. F. Slater, G. T. M. Hult, and E. M. Olson, "Factors influencing the relative importance of marketing strategy creativity and marketing strategy implementation effectiveness," Ind. Market. Manage., vol. 39, no. 4, pp. 551-559, 2010

[105] K. Talke, S. Salomo, and A. Kock, "Top management team diversity and strategic innovation orientation: The relationship and consequences for innovativeness and performance," J. Product Innov. Manage., vol. 28, no. 6, pp. 819-832, 2011

[106] D. J. Teece, "The foundations of enterprise performance: Dynamic and ordinary capabilities in an (economic) theory of firms," Acad. Manage. Perspectives, vol. 28, no. 4, pp. 328-352, 2014.

[107] D. J. Teece, G. Pisano, and A. Shuen, "Dynamic capabilities and strategic management," Strategic Manage. J., vol. 18, no. 7, pp. 509-533, 1997.

[108] M. J. Tippins and R. S. Sohi, "IT competency and firm performance: Is organizational learning a missing link?," Strategic Manage. J., vol. 24, no. 8, pp. 745-761, 2003

[109] M. Uhl-Bien, "Relational leadership theory: Exploring the social processes of leadership and organizing," Leadership Quart., vol. 17, pp. 654 676, 2006.

[110] D. Vrontis, A. Thrassou, G. Santoro, and A. Papa, "Ambidexterity, external knowledge and performance in knowledge-intensive firms," $J$. Technol. Transfer, vol. 42, no. 2, pp. 374-388, 2017.

[111] D. Wang, D. A. Waldman, and Z. Zhen, "A meta-analysis of shared leadership and team effectiveness," J. Appl. Psychol., vol. 99, pp. 181198, 2014.

[112] N. Wang, H. Liang, W. Zhong, Y. Xue, and J. Xiao, "Resource structuring or capability building? An empirical study of the business value of information technology," J. Manage. Inf. Syst., vol. 29, no. 2, pp. 325-367, 2012.

[113] Y. Wang, B. Guo, and Y. Yin, "Open innovation search in manufacturing firms: The role of organizational slack and absorptive capacity," J. Knowl. Manage., vol. 21, no. 3, pp. 656-674, 2017.

[114] Y. C. Wu, B. W. Lin, and C. J. Chen, "How do internal openness and external openness affect innovation capabilities and firm performance?," IEEE Trans. Eng. Manage., vol. 60, no. 4, pp. 704-716, Nov. 2013.

[115] F. J. Yammarino, E. Salas, A. Serban, K. Shirreffs, and M. L. Shuffler, "Collectivistic leadership approaches: Putting the "we" in leadership science and practice," Ind. Org. Psychol., vol. 5, pp. 382-402, 2012.

[116] M. Zhang and J. L. Hartley, "Guanxi, IT systems, and innovation capability: The moderating role of proactiveness," J. Bus. Res., vo. 90, pp. 75-86, 2018.

[117] Z. Zhang, D. A. Waldman, and Z. Wang, "A multilevel investigation of leader-member exchange, informal leader emergence, and individual and team performance," Personnel Psychol., vol. 65, no. 1, pp. 49-78, 2012.

[118] X. Zhao, J. G. Lynch, and Q. Chen, "Reconsidering Baron and Kenny: Myths and truths about mediation analysis," J. Consum. Res., vol. 37, no. 2, pp. 197-206, 2010. 